\title{
Multistage artificial aging optimization for tensile properties of Duralium using Response Surface Method (RSM)
}

\author{
Poppy Puspitasari ${ }^{12^{*}}$, Dewi Izzatus Tsamroh ${ }^{3}$, Mochamad Achyarsyah $^{4}$, Beny Bandanajaya $^{4}$ \\ and Dewi puspitasari ${ }^{5}$ \\ ${ }^{1}$ Department of Mechanical Engineering, Faculty of Engineering, State University of Malang, 65145 \\ Malang, Indonesia \\ ${ }^{2}$ Center of Advanced Materials, State University of Malang, 65145 Malang, Indonesia \\ ${ }^{3}$ Department of Mechanical Engineering, Postgraduate Program, State University of Malang, 65145 \\ Malang, Indonesia \\ ${ }^{4}$ Department of Foundry Engineering, Bandung Manufacturing Polytechnic, 40135 Bandung, \\ Indonesia \\ ${ }^{5}$ Department of Mechanical Engineering, University Technology Petronas, 32610 Seri Iskandar, \\ Perak Darul Ridzuan, Malaysia
}

\begin{abstract}
This study developing mathematical model to optimize heat treatment process to obtain the most significant parameter that affected tensile strength of duralium through multistage artificial aging. The process parameters in this study were temperature of aging, holding time of aging, and artificial aging process was conducted in double stages. The experiments were conducted according to central composite design matrix. The adequacy of developed model was analysed by analysis of variance (ANOVA). The optimum parameter of multistage artificial aging was obtained for maximum tensile strength of duralium.
\end{abstract}

\section{Introduction}

The application of aluminum alloy in industries has been increased rapidly [1]. The used of aluminum alloy had been started from $19^{\text {th }}$ century with consumption 200 tons per year. In 2015, consumption of aluminum alloy reached 58 million tons per year. In 2016, Industrial Ministry of Republic Indonesia targeted Inalum which is aluminum company in Indonesia would produce aluminum as many as $1.5-2$ million tons in 2020 . The worldwide aluminum used by industry in 2015 had been dominated by transportation industry with percentage $26.6 \%$ and construction with percentage $25.3 \%$. Particularly, the use of aluminum alloy in aircraft industrial that reaches almost $90 \%$ [2]. Duralium is aluminum alloy that consists of aluminum and copper that widely used in transportation industry since 1980 [3]. In 1990, duralium was used in airship akron that made by Good Year Zeppelin

\footnotetext{
* Corresponding author: poppy@um.ac.id
} 
Corporation - Germany. Duralium is not only applied in transport industry, but also in others field such as household appliances, components of regulator, military parts and construction of nuclear [4]. Duralium often used in transportation industry due to its properties that has high strength to the weight ratio, duralium also has the other characteristics such as lightweight, high strength, inexpensive, easy to be fabricated and also resists from corrosion [5], [6]. Duralium composed of 3\%- $4.5 \%$ of $\mathrm{Cu} ; 0.4 \%-1 \%$ of $\mathrm{Mg} ; 0 \%-0.7 \%$ of $\mathrm{Mn} ; 0.4 \%-1 \%$ of $\mathrm{Ir} ; 0.3 \%-0.6 \%$ of $\mathrm{Si}$ and the amount of $\mathrm{Al}$ adjusts to the composition [3]. Compared with the others commercial material such as iron and steel, duralium has lower strength that need to be improved. Duralium should have the higher strength to enlarge its applied in industry.

Mechanical properties of duralium can be improved by performing several treatments, such as alloying, cold working, giving heat treatment, and also aging [7], [8]. Duralium is kind of non-ferrous alloy that consists of aluminium, copper, and magnesium that is light, has good corrosion resistance, wear resistance and high fatigue resistance (durability) [9]. Thus, mechanical properties of duralium can be improved by conducting multistage artificial aging [7]. Multistage artificial aging is one of heat treatment method with several stage of artificial aging. Artificial aging is heat treatment process that conducted in particular temperature and holding time. In this study, artificial aging started with solution treatment, quenching with dromus oil and followed with aging process. Artificial aging process will arise the precipitate, then the precipitate will form groups of precipitate. This step will reinforce the material optimally [10]. Artificial aging conducted at temperature between $100^{\circ} \mathrm{C}-200^{\circ} \mathrm{C}$ for $1-24$ hours [11]. Artificial aging has two important parameters that contributes in mechanical properties improvement of duralium, they are temperature aging and duration of holding time. Previous study showed that mechanical properties of duralium was not only affected by temperature aging and holding time, but also the number of stage (multistage artificial aging), and the best result showed artificial aging in double stages [7]. This study focused on determining optimal parameters that improving the tensile strength of duralium on multistage artificial aging by using Response Surface Method.

\section{Experimental Work}

\subsection{Experimental Procedure}

Heat treatment process were performed in a furnace Costruzione Forni Electrick 380V. Artificial aging was started with solution heat treatment at $520^{\circ} \mathrm{C}$ for 30 minutes, then followed by dromus oil quenching to room temperature. Duralium artificially aged in range from $130^{\circ} \mathrm{C}-220^{\circ} \mathrm{C}$ for 4 hours -15 hours. Based on previous study, showed that the best result of multistage artificial aging was multistage artificial aging with double stage as showed in Figure 1. The tensile test specimen was formed according to ASTM-E464 standard [12]. The tensile test was conducting by using a universal testing machine. The sample speciments were also prepared for micro structurel examination as per the standard procedure of grinding and polishing by etching in HF solution. Optical microscopy was performed to understand the distribution of $\mathrm{CuAl}_{2}$ particles. The following table showed multistage artificial aging parameters and their levels that used for optimizing process.

Table 1. Multistage artificial aging parameters and their levels.

\begin{tabular}{|c|c|c|c|c|c|}
\hline \multirow{2}{*}{ Parameters } & \multicolumn{5}{|c|}{ Level } \\
\cline { 2 - 6 } & -1.424 & -1 & 0 & 1 & 1.424 \\
\hline Temperature of Aging $\left({ }^{\circ} \mathrm{C}\right)$ & 130 & 150 & 175 & 200 & 220 \\
\hline $\begin{array}{c}\text { Holding Time of Aging } \\
\text { (hours) }\end{array}$ & 4 & 6 & 8 & 12 & 15 \\
\hline
\end{tabular}




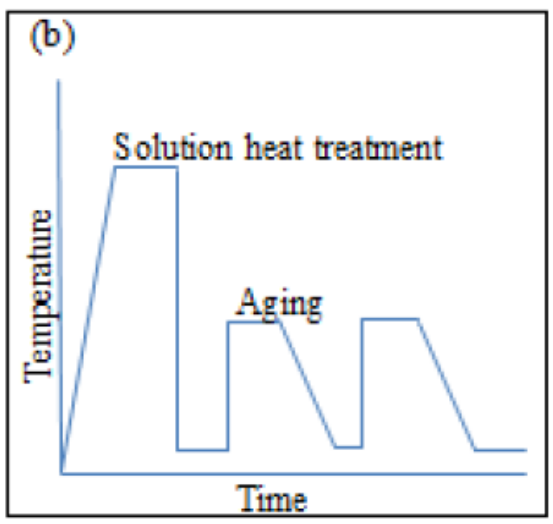

Fig. 1. Schematic diagram of multistage artificial aging

\subsection{Response surface method}

Response surface method (RSM) is an approach that used to determine the relationship between various process parameters with the various with the various machining criteria and explore the effect of these process parameters on the coupled responses, i.e. tensile strength [13]. The equation of the second-order polynomial response surface method:

$$
Y_{u}=b_{0}+\sum_{i=1}^{k} b_{i} x_{i}+\sum_{i=1}^{k} b_{i i} x_{i}^{2}+\sum_{j>1}^{k} b_{i j} x_{i} x_{j}
$$

where $Y_{u}$ is response; $x_{i}(1,2, \ldots, k)$ is the coded level of $k$ quantitative variables; $b_{0}$ is the constatnt term, where $b_{i}, b_{i i}, b_{i j}$ are the coefficients of the linear equation. The non linear form of Eq. (1) was converted into a linear form through the logarithmic transformation. It was used to develop response surface regression form. To created the calculation method, a software package minitab was used to find out the coefficients of mathematical modeling based on the response surface regression form. The level of parameter chosen for the trial that was given in Table 1. Thirteen experiments were conducted according to the central composite design. The experimental design matric and results were given in Table 2 .

Table 2. Mechanical properties of duralium

\begin{tabular}{|c|c|c|c|}
\hline No & Temperature of Aging $\left({ }^{\circ} \mathrm{C}\right)$ & $\begin{array}{c}\text { Holding Time of Aging } \\
\text { (hours) }\end{array}$ & $\begin{array}{c}\text { Tensile strength } \\
\left(\mathrm{kgf} / \mathrm{mm}^{2}\right)\end{array}$ \\
\hline 1 & 175 & 8 & 33.33 \\
\hline 2 & 175 & 8 & 34.45 \\
\hline 3 & 175 & 4 & 30.50 \\
\hline 4 & 175 & 15 & 36.30 \\
\hline 5 & 175 & 8 & 34.20 \\
\hline 6 & 130 & 8 & 30.15 \\
\hline 7 & 150 & 6 & 31.58 \\
\hline 8 & 175 & 8 & 34.25 \\
\hline 9 & 200 & 6 & 32.33 \\
\hline 10 & 220 & 8 & 32.60 \\
\hline 11 & 200 & 12 & 36.80 \\
\hline 12 & 175 & 8 & 34.30 \\
\hline 13 & 150 & 12 & 33.50 \\
\hline
\end{tabular}




\subsection{Analysis of variance}

Analysis of variance for tensile strength of duralium was presented in Table 3. Related $P$ value for the model is less than 0.05 (level of significance $\alpha=0.05$, or $95 \%$ confidence limit), which indicated that model was able to measure statically considerable. The result showed that temperature of aging had effect on the tensile strength of duralium.

Table 3. Analysis of variance (ANOVA) for tensile strength of duralium

\begin{tabular}{|l|c|c|c|c|c|}
\hline Source of variation & $\begin{array}{c}\text { Degree of } \\
\text { freedom }\end{array}$ & $\begin{array}{c}\text { Sum of } \\
\text { squares }\end{array}$ & $\begin{array}{c}\text { Mean } \\
\text { sum of } \\
\text { squares }\end{array}$ & $F$ value & $P$ value \\
\hline Regression & 5 & 43.37 & 8.67 & 15.35 & 0.001 \\
\hline Linear & 2 & 33.67 & 16.84 & 29.80 & 0.000 \\
\hline Square & 2 & 8.07 & 4.04 & 7.14 & 0.020 \\
\hline Interaction & 1 & 1.626 & 1.626 & 2.88 & 0.134 \\
\hline Lack of Fit & 3 & 3.17 & 1.056 & 5.36 & 0.069 \\
\hline Error & 4 & 0.78 & 0.196 & & \\
\hline Total & 12 & & & & \\
\hline
\end{tabular}

\section{Results and discussion}

In this study the effect of aging temperature and holding time of aging on precipitation hardening process. The sequence of operations were solutionizing at $520^{\circ} \mathrm{C}$ for 30 minutes and artificially aging at different temperatures $\left(130^{\circ} \mathrm{C}-220^{\circ} \mathrm{C}\right)$ over time period for $4-15$ hours. The speciment were tested for tensile strength.

\subsection{Tensile properties}

The tensile strength of duralium increased from $30.5 \mathrm{kgf} / \mathrm{mm}^{2}$ (raw material) to 36.80 $\mathrm{kgf} / \mathrm{mm}^{2}$ in $200^{\circ} \mathrm{C}$ for 12 hours. This is due to the presence of $\mathrm{CuAl}_{2}$ precipitate that formed (Figure 2). The tensile strength decreased from $36.80 \mathrm{kgf} / \mathrm{mm}^{2}$ to $32.60 \mathrm{kgf} / \mathrm{mm}^{2}$ in over heating condition $\left(220^{\circ} \mathrm{C}\right.$ for 8 hours). This is due to the aging at the higher temperature (over than $200^{\circ} \mathrm{C}$ ) leaded to softening process [14].

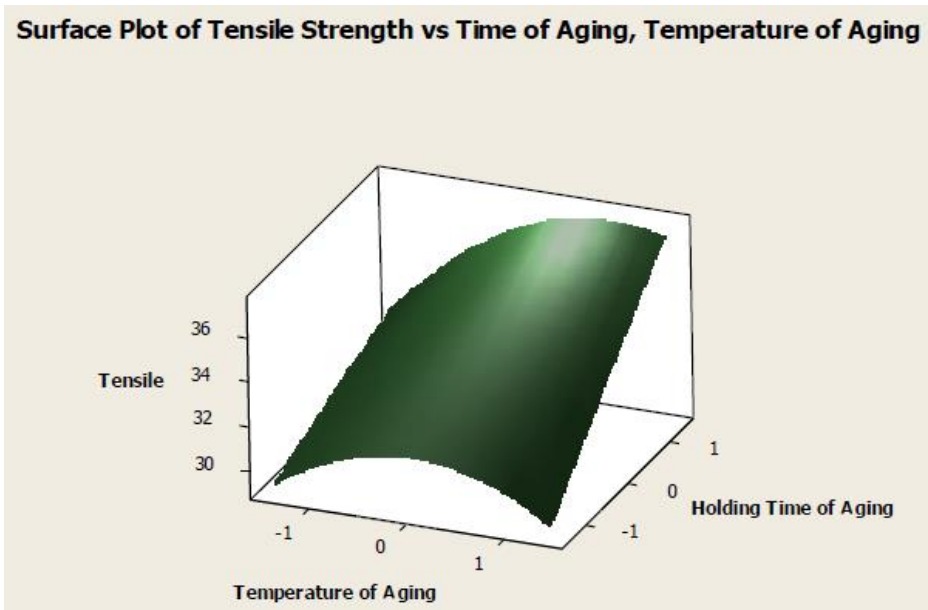

Fig. 2. Tensile strength of duralium 


\subsection{Microstructure of duralium}

The following figures were the microstructure of duralium in the maximum condition and duralium in over heating condition.

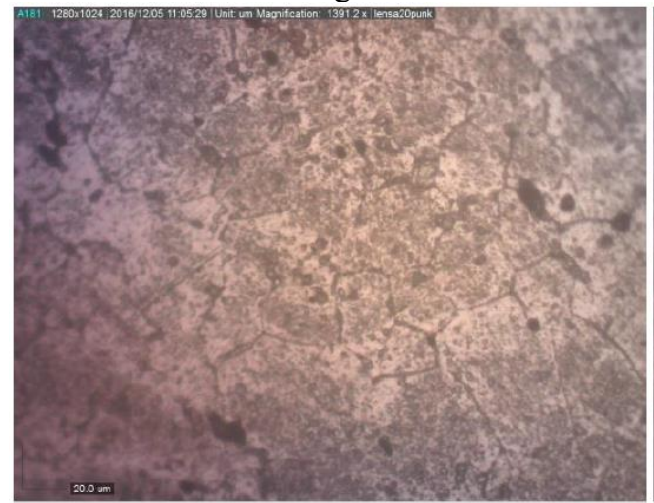

(a)

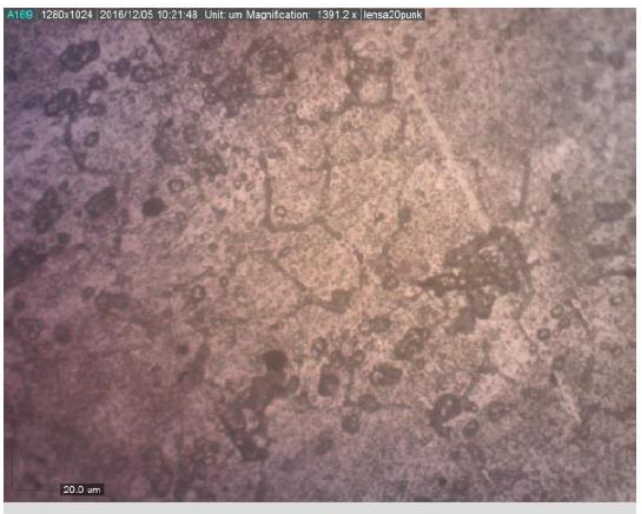

(b)

Fig. 3. Microstructure of duralium at 1300x magnification. (a) duralium artificially aged at $200^{\circ} \mathrm{C}$ for 12 hours, (b) duralium artificially aged at $220^{\circ} \mathrm{C}$ for 8 hours

Figure 3 (a) showed the microstructure condition of duralium that artificially aged at $200^{\circ} \mathrm{C}$ for 12 hours, the figure showed that percipitate of $\mathrm{CuAl}_{2}$ formed that indicated by black spot and the grain boundaries formed clearly. The precipitate also distributed evenly and located inside grain boundaries, this condition gave reinforcement effect against duralium [15]. Figure 3 (b) showed the microstructure condition of duralium that artificially aged at $220^{\circ} \mathrm{C}$ for 8 hours. This condition was over heating condition that made the tensile strength of duralium decreased. The figure showed that precipitate of $\mathrm{CuAl}_{2}$ formed that indicated by black spot but did not distribute evenly. Distribution of precipitate also affected the mechanical properties of duralium [7].

\section{Conclusion}

Based on the explanations above there are several conclusion as follow:

1. The second-order polynomial models were developed to predict the tensile strength using the response surface method.

2. The response surface method was used to study the effects if parameters and their interaction on tensile strength.

3. Temperature of aging had more influence on the tensile strength of duralium compared to holding time of aging parameter.

4. Based on the developed mathematical model, optimal parametric combination, i.e., artificial aging at $200^{\circ} \mathrm{C}$ for 12 hours with tensile strength of $36.80 \mathrm{kgf} / \mathrm{mm}^{2}$

The author would like to thank Ministry of Research, Technology, and Higher Education of Republic Indonesia for Hibah Penelitian Berbasis Kompetensi 2018 with contract no. 1.3.32/UN.14/LT/2018.

\section{References}

1. P. Puspitasari, D. Puspitasari, M. I. N. Sasongko, Andoko, dan H. Suryanto, AIP Conf. 
1778 0-4 (2016)

2. P. Rambabu, N. E. Prasad, dan V. V Kutumbarao, (2017)

3. P. D. Merica, R. G. Waltenberg, dan H. Scott, Sci. Pap. 271-315, (1919)

4. K. Lee, S. Yang, dan J. Yang, Int. J. Adv. Manuf. Technol, (2016)

5. E. Ghassemieh, New Trends Dev. Automot. Ind. 365-394 (2011)

6. Anne Zulfia, Ratna Juwita, Ari Uliana, I Nyoman Jujur, dan Jarot Raharjo, J. Tek. Mesin 12 13-20 (2010)

7. D. I. Tsamroh, P. Puspitasari, Andoko, M. I. N. Sasongko, dan C. Yazirin, vol. 20070 20070 (2017)

8. J. Mulyanti, J. Kompetensi Tek. 2 95-104 (2011)

9. A. Feni, 1-10.

10. M. Chacko dan J. Nayak, Int. J. Chem. Mol. Nucl. Mater. Metall. Eng, 8 195-198 (2014)

11. W. F. Smith, H. Javad, dan R. Prakash, Introduction to Materials Science and Engineering (2015)

12. ASTM Int., "Standard Test Methods for Tension Testing of Metallic Materials 1," Astm 1-27 (2009)

13. M. Dastkhoon, M. Ghaedi, A. Asfaram, A. Goudarzi, S. M. Mohammadi, dan S. Wang, Ultrason. Sonochem, 37 94-105 (2017)

14. A. Cochard et al, Mater. Sci. Eng. A, 690 259-269 (2017)

15. S. Jin, T. Ngai, G. Zhang, T. Zhai, S. Jia, dan L. Li, Mater. Sci. Eng. A, 724 53-59 (2018) 